A Quasi-2D Bayesian network model for assessments of coastal inundation pathways and probabilities

Siddharth Narayan ${ }^{1}$, Dave Simmonds ${ }^{2}$, Robert J. Nicholls ${ }^{1}$, Derek Clarke ${ }^{1}$

1: Energy and Climate Change Division, Faculty of Engineering and the Environment, University of Southampton, Southampton, UK

2: School of Marine Science and Engineering, Faculty of Science and Environment, University of Plymouth, Plymouth, UK 


\title{
A Quasi-2D Bayesian network model for assessments of coastal inundation pathways and probabilities
}

\begin{abstract}
Coastal flood assessments often require the analysis of a complex system of flood sources, pathways and receptors. This can be challenging for traditional numerical modelling approaches. In this paper we use a Bayesian networks approach to assess coastal floodplains as networks of inter-linked elements. A Bayesian network ( $\mathrm{Bn}$ ) model is built to describe flood pathways and estimate flood extents for different extreme events. The network of the $\mathrm{Bn}$ model is constructed from a quasi-2D Source - Pathway - Receptor (SPR) systems diagram. The Bn model is applied in Teignmouth in the UK, a coastal floodplain of typical complexity. It identifies two key flood pathways and assesses their sensitivity to changes in sea levels, beach widths and coastal defences. The advantages, utility and limitations of the Teignmouth Bn model are discussed. The process of 2D SPR and Bn model construction helps identify gaps in floodplain understanding and description. The $\mathrm{Bn}$ model quantifies inundation probabilities and facilitates the rapid identification of critical pathways and elements, before committing resources to further detailed analysis. The approach is transferable and can be readily applied in local-scale coastal floodplains to obtain a systems-level understanding and inform numerical modelling assumptions.
\end{abstract}

Key words: Bayesian networks; coastal; flood pathways; flood risk; inundation; network model; sea level rise; Source - Pathway - Receptor

\section{Introduction}

Cities and towns in coastal regions lie at the interface between human, physical and natural systems. As these regions continue to grow in size and population they are also increasingly exposed to flood damage due to rising sea levels and there are concerns of more intense and frequent storms (Kron, 2013, McGranahan et al., 2007, Hallegatte et al., 2013). Mitigating the risk of flooding requires consideration of all human, physical and natural elements lying within the coastal floodplain (Hall et al., 2003, Mokrech et al., 2011).

A typical risk assessment would use a chain of numerical models to assess the magnitude of flood sources, behaviour of flood defences and the extent and characteristics of floodplain inundation. In this chain the outputs of the first model provide the inputs to the next and so on (Villatoro et al., 2014, Zou et al., 2013, Purvis et al., 2008). The conceptual models in such an assessment generally describe the floodplain linearly using the popular Source - Pathway - Receptor (SPR) model (Sayers et al., 2002). Such models reduce the spatial relationships between floodplain elements to the simplest of representations (Figure 1). Larger, more complex floodplain systems require more comprehensive descriptions in order to assess the different flood sources, pathways and receptors (Narayan et al., 2012a). 


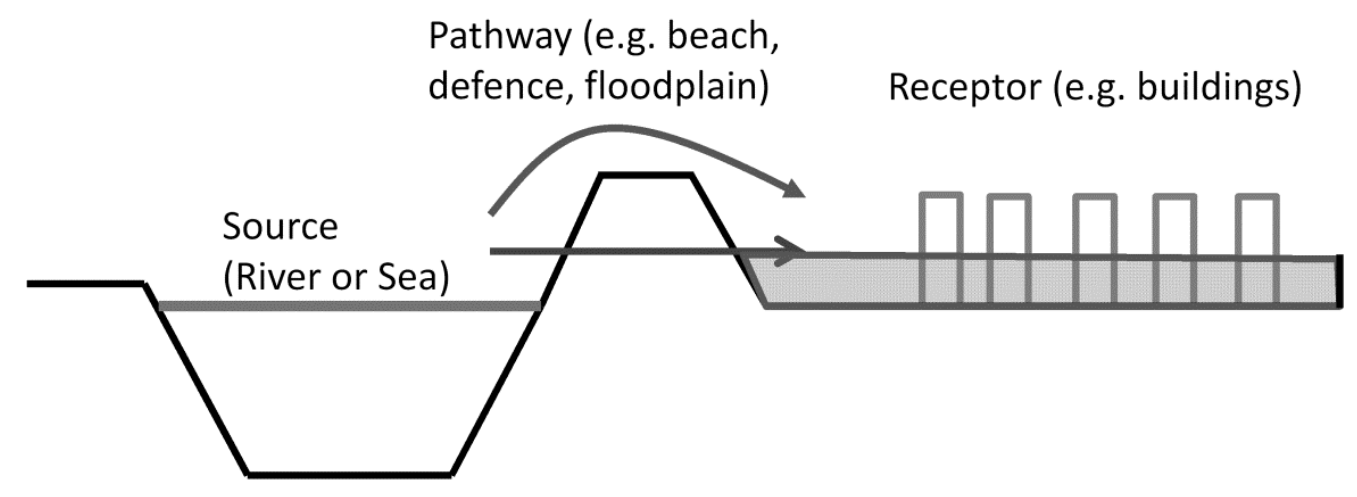

Figure 1: The Source - Pathway - Receptor (SPR) conceptual model (adapted from FLOODSite Consortium, 2009)

The Quasi-2D SPR is another conceptual model that describes the floodplain as a system of spatially distributed and inter-related source, pathway and receptor elements. It provides a comprehensive, qualitative, spatial description of the floodplain. This floodplain description is built by coastal flooding experts and stake-holders in a participative, iterative process of knowledge-elicitation and consensus-building (Narayan et al., 2014). The result is a comprehensive system diagram of the floodplain that maps all recognised sources, pathways and receptors of coastal flooding (Figure 2). The model has been applied successfully in eight European coastal regions as the conceptual model of a larger coastal flood and erosion risk mitigation project (Zanuttigh et al., 2014). The Quasi - 2D SPR however stops short of assessing the relative importance or sensitivities of mapped flood pathways. To do this, the role and relationships between different pathways and elements must be quantified (Monbaliu et al., 2014). Such quantification will require extending the Quasi-2D SPR to a network model.

There are several types of network models such as logical (Boolean) dependency models, fault trees, and $\mathrm{Bn}$ models that are used to analyse relationships between non-spatial network variables. Boolean dependency models use logical relationships derived from expert judgement to predict future system behaviour. For instance, Karunarathna \& Reeve (2008) and French \& Burningham (2011) use Boolean dependency models to predict the geomorphological evolution of a complex estuarine system. Similarly, fault trees are used to construct hierarchical causal chains to investigate the possible pathways to an end result such as, for instance, coastal defence failure (Kortenhaus et al., 2002). Bn models combine graphical theory and Bayes' probability theory to analyse the propagation of probabilities across a network, conditional on the state and inter-relationships of its nodes. For example, Gutierrez et al. (2011) use a Bn model to predict future shoreline evolution along the Atlantic coast of the U.S.A based on sea-level rise, coastal classification and shoreline retreat rates. Yates \& Le Cozannet (2012) use a Bn model of European coastal networks to investigate decadal shoreline evolution in response to sea level and sediment regime changes and find it useful for identifying data and knowledge-gaps in the network. den Heijer et al. (2012) use a $\mathrm{Bn}$ model to assess the response of barrier islands to extreme storm events. These models demonstrate the usefulness of the $\mathrm{Bn}$ approach in analysing networks of different variable types where there are gaps and uncertainties in our knowledge of the network.

Bn models are also useful in spatial and non-spatial assessments of flood damage and flood risk. (Peng and Zhang, 2012) use a Bn model of fifteen variables to predict the influence of different 
factors: hydraulic, topographic, environmental and human on the potential loss of life from a dambreak event. The advantage of the $\mathrm{Bn}$ model is its ability to account for a large number of different parameters. In another fluvial network analysis, (Stewart-Koster et al., 2010) use a Bn model of fluvial flow variables to help optimise investment decisions in flow regulation. In a spatial coastal flood impact assessment, Schultz (2012) uses a Bn model for assessments of operational impacts of storm events on port facilities. The model successfully provides a preliminary overview of the flood sources and pathways that affect port facilities during a storm.

These applications demonstrate the usefulness of Bn models in analysing spatial and non-spatial networks consisting of variables with different properties and relationships. The relationships between variables can be defined using statistical data, qualitative knowledge (i.e. expert judgement), or logical or empirical relationships (Peng and Zhang, 2012, Kelly et al., 2013). Descriptions of coastal flood plans are often complicated in that they require a range of variables of many data types, and a comprehensive set of definitions to estimate flood propagation. Bn models are highly efficient tools for estimating the propagation of node probabilities in large networks. As such, they are a good approach for quantitative network assessments of the coastal floodplains described by the Quasi-2D SPR.

This paper discusses the development of a spatially explicit Bn model for rapid, quantitative description and assessment of inundation pathways for coastal flood events. The aim is to provide preliminary quantitative information on these pathways to inform the structure and choice of key assumptions in further numerical modelling efforts. The Bn model uses the Quasi-2D SPR to construct its network, and known flow-routing relationships to quantify inundation probabilities at the network nodes. The ability of the Bn model to describe flood extents and identify critical elements and inundation pathways is tested by application in an urban coastal floodplain in the UK.

\section{Bayesian Network Model Construction Methodology}

The first step in building the Bn model is developing its Quasi-2D SPR map and system diagram. The process for the Quasi-2D SPR system diagram (Figure 2) is as follows (Narayan, 2014):

1. The landward boundaries of the coastal floodplain are identified using a planar water level (bath tub) model for the most extreme coastal flood event being assessed, with flood protection and defence elements removed. Flood extents for selected lower-magnitude flood events are also mapped by the bath tub method.

2. A map with land-use and elevation information is created using a vector mapping process. All flood sources and the floodplain, including inter-tidal zones (i.e. beaches, coastal habitats), are mapped as identifiably independent elements based on land-use. In this process floodplain elements recognised as critical to flood propagation are also defined. This could include linear features such as roads, railway lines and defence structures and 'point' features such as water treatment plants or flood pumps.

3. Element size is flexible and primarily decided based on the scale of application of the model and land-use (also see Narayan et al., 2012b). If digital elevation data is available, the average height of each floodplain element is determined using GIS. In floodplains with rapidly varying topography the lowest flood level of interest can be used to limit the size of each element. 
4. The floodplain elements are schematised to obtain the Quasi-2D SPR systems diagram, with links drawn between any two elements that share a boundary.
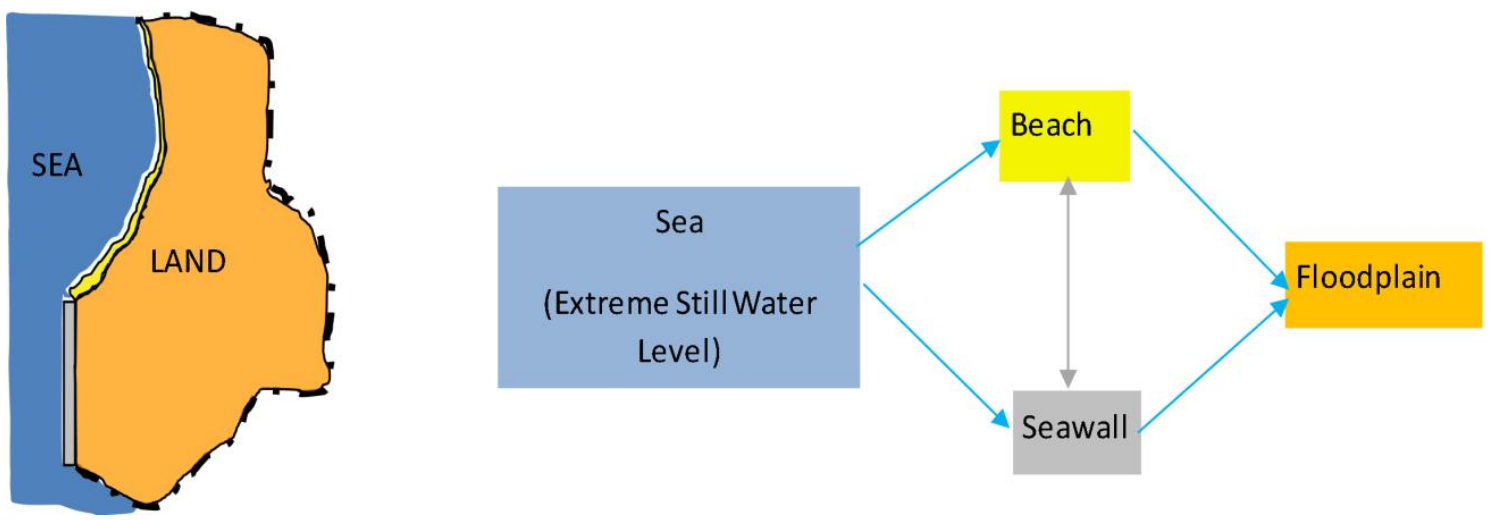

Figure 2: Left: Land-use map of a generic coastal floodplain; Right: Quasi-2D SPR system diagram for floodplain (blue arrows show hydraulic links, grey arrow shows morphological influence)

The $\mathrm{Bn}$ model is derived from the Quasi-2D SPR system diagram. Each network node, $\mathrm{N}$ maps to a corresponding Quasi-2D SPR element $\mathrm{E}$ and its average height, $\mathrm{h}$ is the average height of the element E. A node $\mathrm{N}$ is described in terms of its flood state, expressed in the form of a discretised probability distribution whose sum is always 1 . Each link in the Bn model network corresponds to a link in the Quasi-2D SPR system diagram. The network model is built specifically for inundation analysis and links between network nodes represent flood routing across the network. A link between two nodes indicates a flow from the upstream node to the downstream node (see Figure 3).

Figure 3 shows estimated flood state probabilities at the floodplain nodes, for an input probability distribution at the 'Extreme Still Water Level' (ESWL) node. The flood states of the inland nodes are driven by the probability distribution of the input node 'Extreme Still Water Level'. For each node the percentage probabilities of each of its states are indicated. Thus, the Beach node has two states, 'Flooded' and 'Dry' with estimated probabilities of $94.59 \%$ (rounded off to $94.60 \%$ in Figure 2 ) and $5.41 \%$ respectively. Flood propagation calculations for this illustrative network are described in Equations (1) to (8) below.

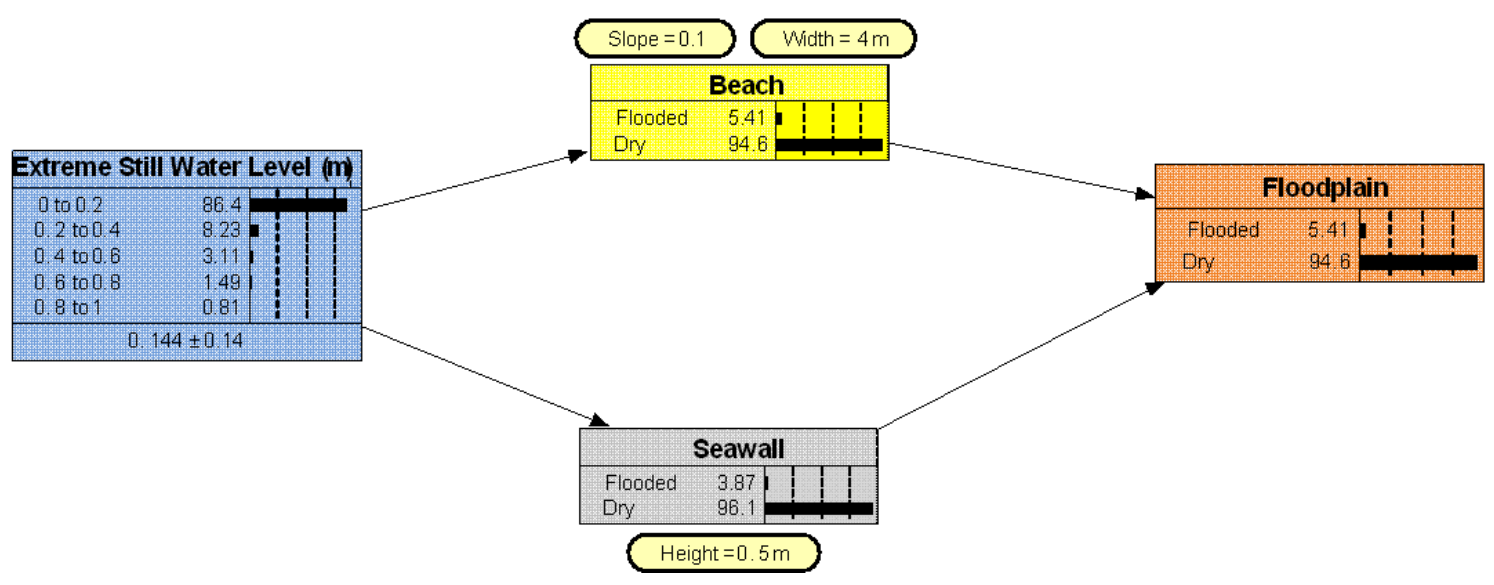

Figure 3: Network of Bn model for inundation derived from Quasi-2D SPR in Figure 2 
For ease of representation let, Extreme Still Water Level $(E S W L)=w$; Event (Beach=Flooded $)=D_{1}$; Event $($ Seawall=Flooded $)=D_{2}$; Event $($ Floodplain $=$ Flooded $)=F$; Event $($ Beach $=$ Dry $)=\overline{D_{1}} ;$ Event (Seawall=Dry) $=\overline{D_{2}}$; and Event (Floodplain $=$ Dry) $=\bar{F}$.

In general, the ESWL, $\mathrm{w}$ is specified as an extreme value Weibull distribution with shape parameter $a=0.5$ and scale parameter $b=0.055$,

$p(w)=\operatorname{Weibull}(w, a, b)$

In the $\mathrm{Bn}$ model, this distribution is discretised into five states. The Beach, Seawall and Floodplain nodes are Boolean nodes with two states - flooded or dry. The probability of flooding of each of these nodes is conditional on the probability of its input node. To specify their crest heights the Seawall node uses the constant 'Height' and the Beach node uses constants 'Slope' and 'Width'. The probability of the beach being flooded is determined by the probability that its height is less than the input ESWL and is given by

$P\left(D_{1} \mid w\right)= \begin{cases}1, & w>0.4 \\ 0, & \text { otherwise }\end{cases}$

Similarly, the seawall is flooded when its height is less than the ESWL,

$P\left(D_{2} \mid w\right)= \begin{cases}1, & w>0.5 \\ 0, & \text { otherwise }\end{cases}$

The floodplain node is assumed to lie below the beach and seawall nodes in this example and is flooded if at least one of the beach and seawall nodes is flooded. Thus event $\mathrm{F}$ can occur in one of three ways - $D_{1} \cap D_{2}, \overline{D_{1}} \cap D_{2}$ or $D_{1} \cap \overline{D_{2}}$. Therefore $P(F)$ is given by,

$P(F)=P\left(D_{1} \cap D_{2}\right)+P\left(D_{1} \cap \overline{D_{2}}\right)+P\left(\overline{D_{1}} \cap D_{2}\right)$

Grouping the first two terms on the R.H.S we have

$P(F)=P\left(D_{1}\right)+P\left(\overline{D_{1}} \cap D_{2}\right)$

Since the seawall is higher than the beach in this example $P\left(\overline{D_{1}} \cap D_{2}\right)$ is zero. The ESWL node is discretised into 5 states from 0 to 1 . Thus,

$P\left(D_{1}\right)=\sum_{j=0}^{5} p\left(w_{j}\right) \cdot P\left(D_{1} \mid w_{j}\right)$

and,

$P\left(D_{2}\right)=\sum_{j=0}^{5} p\left(w_{j}\right) \cdot P\left(D_{2} \mid w_{j}\right)$

From Equations 5, 6 and 7 and since $P\left(\overline{D_{1}} \cap D_{2}\right)$ is zero,

$P(F)=P\left(D_{1}\right)=\sum_{j=0}^{5} p\left(w_{j}\right) \cdot P\left(D_{1} \mid w_{j}\right)$

Solving Equation 8 we have, $P(F)=0.054$. 
The state of the node 'Floodplain' is an outcome of the combined probability of flooding of 'Seawall' and 'Beach'. Since 'Beach' lies lower than 'Seawall' in this example it forms the critical flood pathway.

These relationships are obvious in this example where estimating node probabilities at three nodes and four links is relatively simple. However this becomes rapidly more complex and difficult as the network grows in size. In such networks, the ability to produce similar simplified insights concerning the inundation pathways will be extremely useful for informing the development of subsequent numerical models. Generally, for a node N in this Bn model,

$P(N)=1=P(N=$ flooded $)+P(N=$ dry $)$

Different node descriptions may be used depending on land-use and node type. For instance, the flood source in the example above is described as a discretised Weibull distribution of water levels. In the case-study, the seawalls are described in terms of overtopping rates (see Table 1).

A node $\mathrm{N}$ also has associated constants that are used by the model in estimating flood propagation. In the example below, the beach has constants 'slope' and 'height' associated with it. At the start of the simulation, all floodplain nodes are assumed to be dry. The flood source nodes are used to estimate the flood states of coastline nodes and these in turn determine the states of downstream nodes. Generally, the flood state of a node $\mathrm{N}$ in a network with $\mathrm{p}$ nodes is estimated as

$P(N=$ flooded $)=\sum_{i=1}^{p} P\left(N u_{i}=\right.$ flooded $\left.\& h(N) \leq h\left(N u_{i}\right)\right)$

Where, $\mathrm{h}$ is the average node height and $N u_{i}$ the upstream node of index $\mathrm{i}$. Similar to the node descriptions different node types can make use of different flood propagation rules. For instance, seawalls in the case study are flooded by overtopping (see Table 1).

This Bn model is built with the commercially available Netica software (Norsys Software Corp, 2010) that uses a technique known as 'compiling' to further optimise the calculation of node probabilities. Repeated calculations on the same network can then be performed rapidly and with greatly reduced computational effort (see Norsys Software Corp, 2010 for details) and changes in node values or descriptions can be rapidly updated. The $\mathrm{Bn}$ model is now applied to a real coastal floodplain whose network consists of more than 50 nodes and 70 links.

\section{Case-Study: Teignmouth, UK}

The Bn model was constructed for Teignmouth, a historic seaside resort at the mouth of the Teign estuary, Devon, UK (Figure 4). The first step was to construct the Quasi-2D SPR for Teignmouth. The inland boundaries for the Quasi-2D SPR and the Bn model are the same, i.e. the maximum floodplain extent for a 1 in 1000 year storm surge event for current sea-levels which is $3.46 \mathrm{mOD}$ (Halcrow Group, 2011). This floodplain covers 1 to $2 \mathrm{~km}^{2}$ and consists of two main flood "compartments", one in the town centre and a smaller compartment in the west. The floodplain is bounded by a railway line to the north, the Teignmouth - Shaldon bridge to the west, the Teign estuary to the south and the open coast to the east. The railway line also divides the central and western flood compartments. Figure 5 shows the land-use map defining the Quasi-2D SPR elements for Teignmouth. Developing the Quasi-2D SPR map and system diagram helped the gathering and 
structuring of the representation of the Teignmouth floodplain, which was then used as the basis for constructing the Bn model.

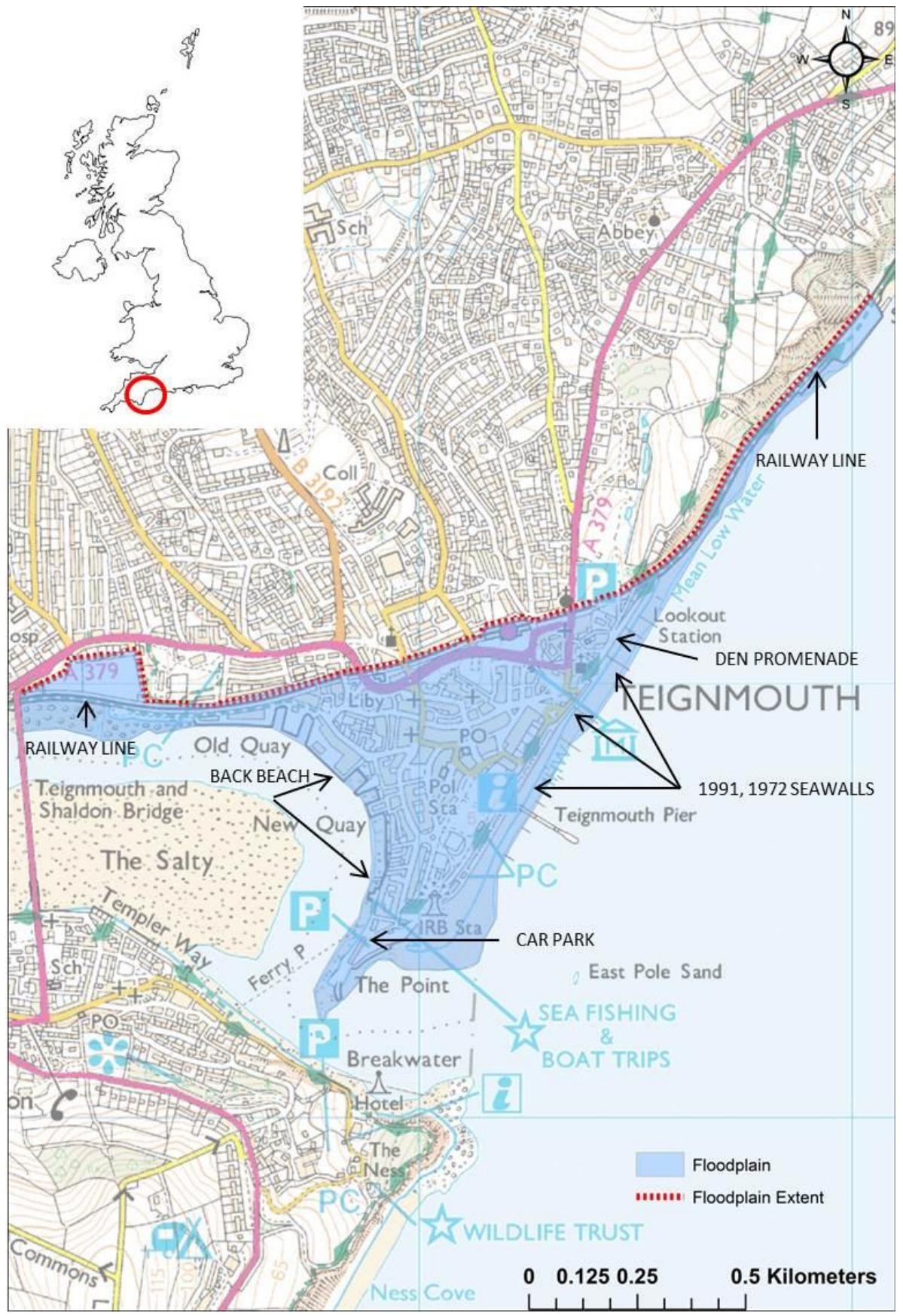

Figure 4: Map of Teignmouth showing floodplain extent and key floodplain elements (Inset: Location of Teignmouth in the UK). This map contains Ordnance Survey data (c) Crown Copyright and database right (2013). 


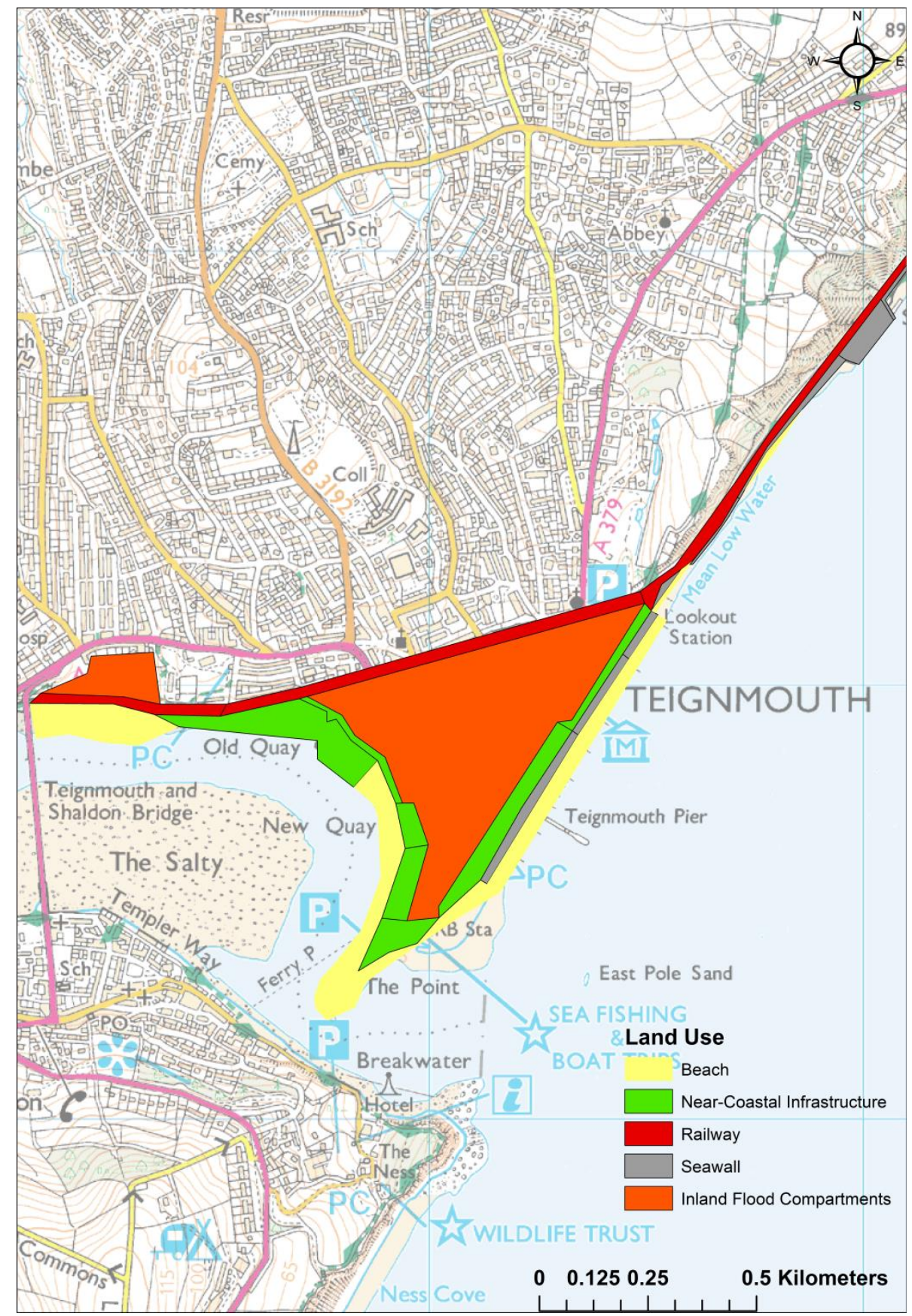

Figure 5: Teignmouth land-use zones and elements for Quasi-2D SPR system diagram (adapted from Narayan, 2014). This map contains Ordnance Survey data (C) Crown Copyright and database right (2013).

Flooding is assumed to occur from coastal flood sources which directly control water levels in the estuary and along the open coast. The town may also be flooded by fluvial sources in the estuary and pluvial runoff from the steep hillside, but these sources are not considered in this work and they are secondary compared to coastal flooding (Environment Agency 2012c). The nature of coastal flooding varies according to the location of the flood source. Due to the peninsular feature on which Teignmouth has developed, the town can flood from different directions: the estuary and the open coast. Flooding along the estuarine coastline is dominated by inundation due to tidal flooding 
whereas flooding along the open coast is driven mainly by wave overtopping, which is in turn driven by water levels and waves in combination.

The pathways into the floodplain also vary by location. The estuarine coastline along the Back Beach area has been flooded in the past, but is now defended by a new $f 4$ million flood defence scheme incorporating flood gates and walls (Vizard, 2012). The open coastline is protected by multiple seawall sections some of which are accompanied by secondary landward defences (walls or walkways) and fronting beaches. The seawall protecting the coastal railway line to the north-east was overtopped in the 2014 winter storms (The South West Coast Path, 2014). Some seawall sections in front of Den Promenade (Figure 4) have been overtopped in the past causing the flooding of the central floodplain. The 'Den Promenade' was also closed due to overtopping in one of the 2014 storm events (Guardian Witness, 2014).

The Quasi-2D SPR system diagram describes all recognised coastal flood sources and floodplain elements (Figure 6). The model uses data from a digital elevation model to obtain the average elevation of each floodplain element. 


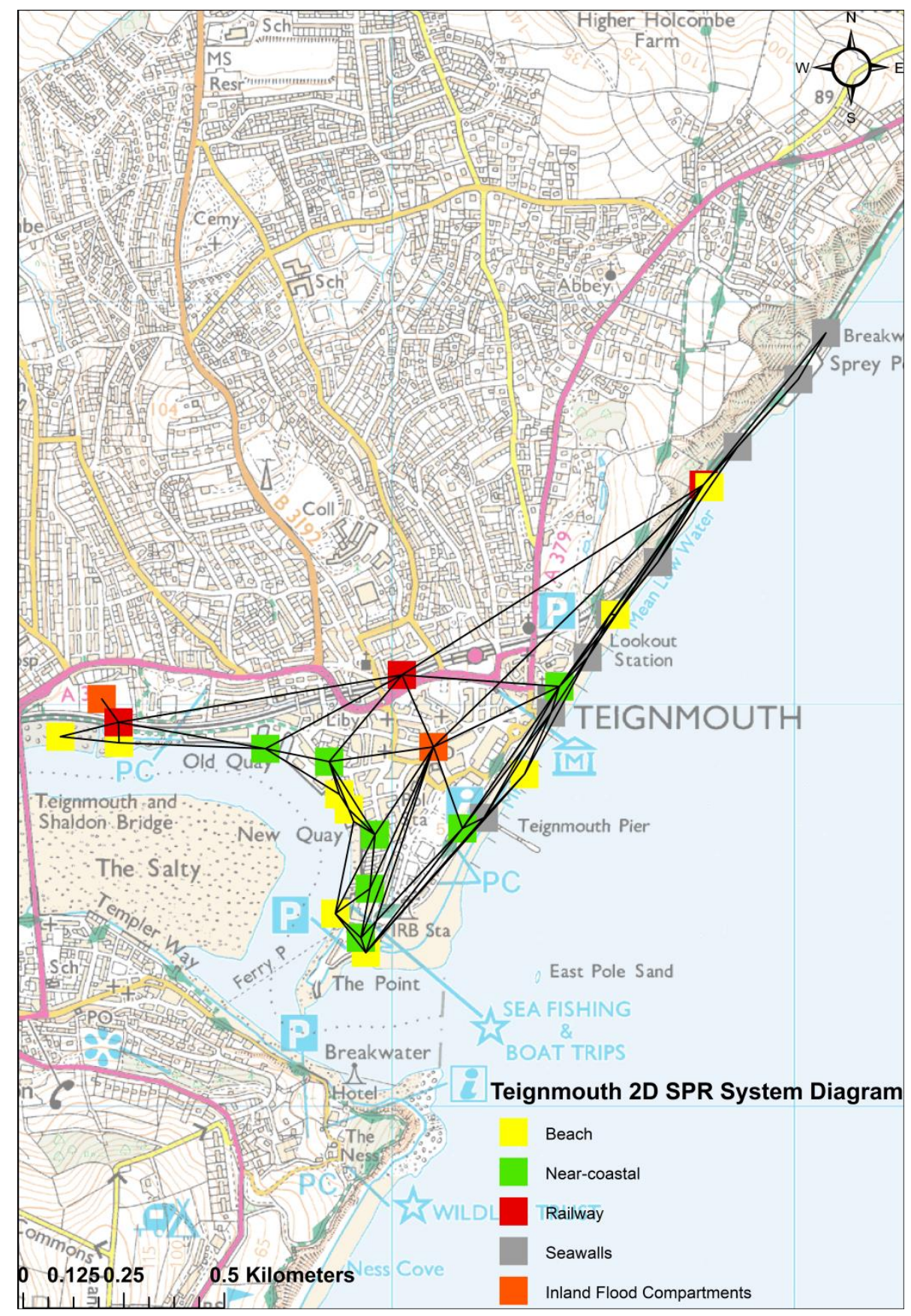

Figure 6: Teignmouth Quasi-2D SPR system diagram (adapted from Narayan, 2014). This map contains Ordnance Survey data (C Crown Copyright and database right (2013).

The Bn model nodes (Figure 7) have a one-to-one correspondence with the Quasi-2D SPR elements. The exception to this is the central Teignmouth floodplain node, which is split in two in the network model to capture possible differences in flooding from open coast and estuarine flood pathways.

The links between nodes are in the direction of flood propagation, i.e. from the flood source, inland. The coastal elements are all linked to a local flood source each in turn linked to an English Channel water level. Flooding at the seawalls and beaches is assumed to be independent of flooding at adjacent coastal nodes, and along-shore links between these are removed. Since beaches can 
influence overtopping rates at landward seawalls, cross-shore links between the open beaches and seawalls are maintained to describe these influences. The network recognises two flood pathway types - inundation pathways from the estuary and overtopping pathways from the open coast. The central 'Teignmouth' node in the Bn model can be flooded by both pathway types - an overtopping pathway from the open coast via the railway line to the north and an inundation pathway from the estuary via the Back Beach. To capture this difference the node is split into two: a northern floodplain linked to the railway line and a southern floodplain linked to the Back Beach nodes.

Other than the seawalls, all nodes are considered flooded if they have a water depth greater than 0 . A seawall is considered flooded if overtopping rates exceed $50 \mathrm{l} / \mathrm{s} / \mathrm{m}$ (based on limits for overtopping for vehicles from EurOtop Manual, 2007). As stated previously flooding from the estuary is by water level driven inundation and the estuarine coastal nodes are described as either 'dry' or 'flooded'. All inland nodes are similarly described as 'dry' or 'flooded'. A node can be flooded if one or more of its upstream linked nodes are flooded and are at a higher elevation. Though highly unlikely, it is possible that in an extreme case of estuarine flooding, nodes along the open coast can be flooded from the estuarine pathways, and vice-versa. This case is however not considered in this paper (see Discussions). The flood source inputs along the estuary are the Extreme Still Water Levels (ESWLs). On the open coast the inputs include the ESWLs, wave heights, wave periods and storm duration.

Flooding from the open coast occurs via overtopping at the seawalls (Table 1). The seawalls are described by a probability distribution of overtopping rates based on empirical equations (EurOtop Manual, 2007; see Table 1). Node parameters such as slope, crest height and elevation are specified as constants based on the most recent coastal engineering reports (Royal Haskoning, 2011, Halcrow Group, 2011, Mouchel Parkman, 2008). Overtopping at the seawalls is influenced by the width of the beaches in front of them. These widths are in turn influenced by sediment input on the open coast. While there are no publicly available records of long-term beach widths it is known that beach widths along the open coast are influenced by the availability of external sediment from up-stream coastal cliffs and by the sand bank behaviour near the estuary mouth (Royal Haskoning, 2011). A 'Sediment Input' node is added (Figure 7) that lets the user indicate the availability of sediment along the open coast. For this application it was decided that sediment availability will be indicated by a choice of beach widths: $0-10 \mathrm{~m}$ in the absence of sediment input, and $10-20 \mathrm{~m}$ when sediment input is available (see Table 1 ).

The $\mathrm{Bn}$ model for Teignmouth is built in only $1-2$ days. Subsequent network simulations require a few minutes to be performed. Each simulation randomly samples 500 values at each node to calculate its flood probabilities based on the conditional relationships described in Table 1 . The nodes classified as dry or flooded according to their flood probabilities and are mapped using GIS software. 


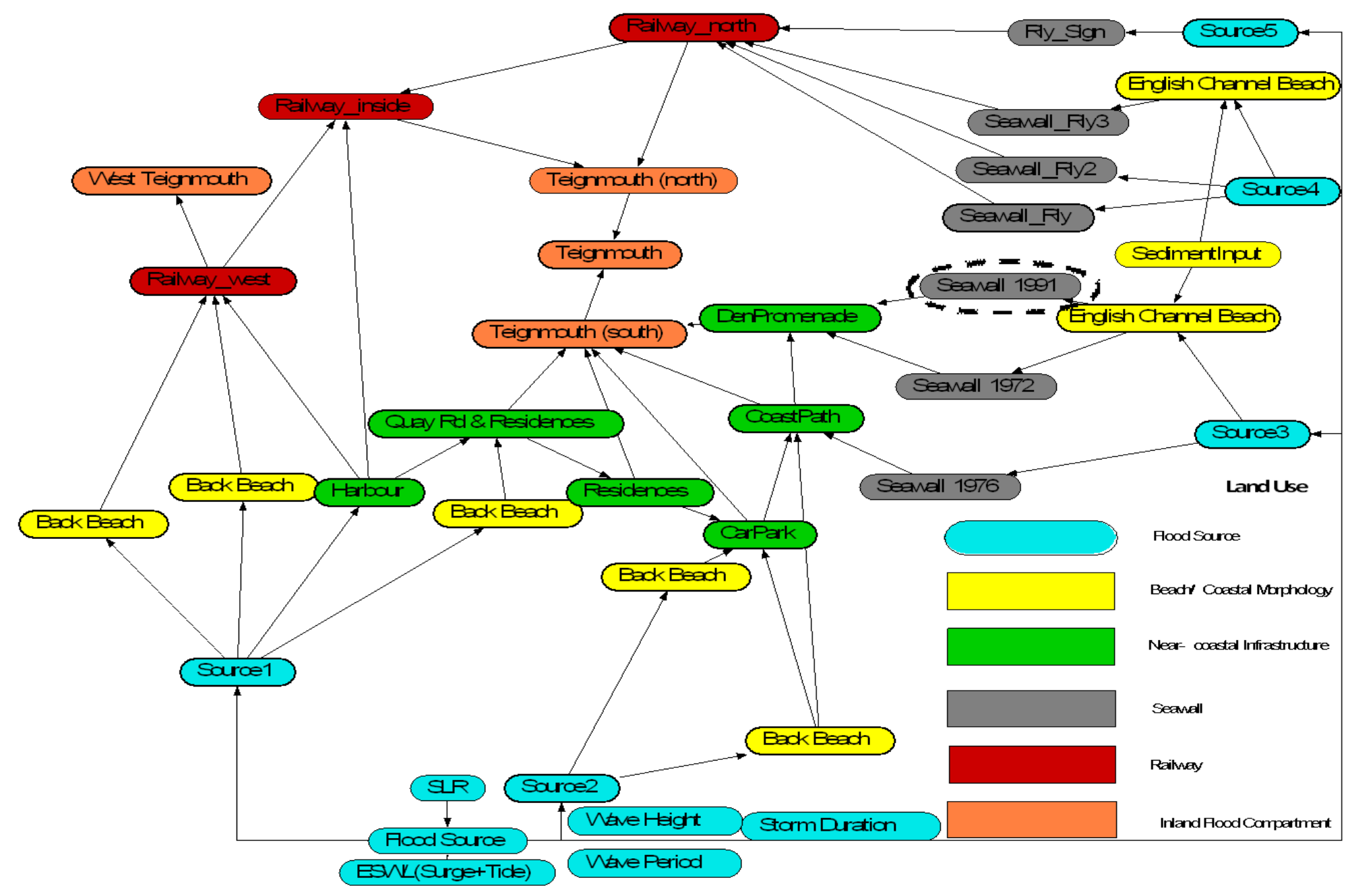

Figure 7: Floodplain network of the Teignmouth floodplain for the Bayesian network inundation model (dashed circle indicates node 'Seawall_1991' used for overtopping comparison in Figure 8) 
Table 1: Node descriptions, relationships, equations and assumptions for Teignmouth Bn model

\begin{tabular}{|c|c|c|c|c|c|c|}
\hline Nodes & $\begin{array}{l}\text { Node Type, } \\
\text { Range and } \\
\text { Units }\end{array}$ & $\begin{array}{l}\text { Node } \\
\text { Description } \\
\text { and Class } \\
\text { Intervals (Cls) }\end{array}$ & $\begin{array}{l}\text { Affected } \\
\text { Nodes }\end{array}$ & $\begin{array}{l}\text { Node Equations and Conditional } \\
\text { Dependency Relationships }\end{array}$ & Associated Constants & Assumptions/Considerations \\
\hline $\begin{array}{l}\text { Flood Sources } \\
\text { (Sources1-5) }\end{array}$ & $\begin{array}{c}\text { Input: Water } \\
\text { Level } \\
0 \text { to } 4.75 \mathrm{~m}\end{array}$ & $\begin{array}{l}\text { Discrete, } 10 \\
\text { user-defined } \\
\text { Cls }(0,2.5 \\
2.75,3,3.37 \\
3.52,3.67,4 \\
4.25,4.5,4.75) \\
\text { Each level is } \\
\text { run in turn. }\end{array}$ & \begin{tabular}{|} 
Open coast \\
Beaches, \\
Seawalls, \\
Estuarine \\
coastal nodes
\end{tabular} & $\begin{array}{c}\text { Flood Source }=E S W L+S L R \\
\text { where } E S W L=\text { Storm Surge }+ \text { Tide }\end{array}$ & \begin{tabular}{|} 
Significant wave \\
height (Hs), peak wave \\
period (Tp), Duration, \\
Extreme Still Water \\
Level (ESWL= surge + \\
tide), Sea-level rise \\
(SLR)
\end{tabular} & $\begin{array}{c}\text { ESWL, SLR, Hs and Tp values are } \\
\text { user-specified (default } \mathrm{Hs}=2 \mathrm{~m}, \mathrm{Tp}= \\
\text { 8s corresponding to a } 1 \text { in } 50 \text { year } \\
\text { return period) }\end{array}$ \\
\hline $\begin{array}{l}\text { Open Coast } \\
\text { Beaches } \\
\text { (Beach_Rly, } \\
\text { Beach_east and } \\
\text { Beach_Rly2) }\end{array}$ & $\begin{array}{l}\text { Input: Beach } \\
\text { width, W } \\
0 \text { to } 20 \mathrm{~m}\end{array}$ & $\begin{array}{l}2 \text { Uniformly } \\
\text { distributed Cis, } \\
\text { user chooses } \\
\text { between } U(0- \\
10) \text { or } U(10-20)\end{array}$ & $\begin{array}{l}\text { Open Coast } \\
\text { Seawalls }\end{array}$ & $\begin{array}{c}\text { If }(S I=\text { present }), W=15 \\
\text { Else If }(S I=\text { absent }), W=5 \\
\text { Else SI = UniformDistribution }(W, 0,20) \\
(12)\end{array}$ & $\begin{array}{l}\text { Sediment Input, SI } \\
\text { slope, } \theta\end{array}$ & $\begin{array}{l}\text { Initial width is } 5 \mathrm{~m} \\
\text { Sediment input adds } 10 \mathrm{~m} \text { width } \\
\text { Beach profile is triangular }\end{array}$ \\
\hline $\begin{array}{c}\text { Open Coast } \\
\text { Seawalls } \\
\text { (Seawalls 76, 72, } \\
91, \text { Rly, Rly2, Rly3 } \\
\text { and Rly_Sign) }\end{array}$ & $\begin{array}{l}\text { Modelled: } \\
\text { Overtopping } \\
\text { rate, q for } \\
\text { vertical } \\
\text { seawall } \\
-10 \text { to } 110 \\
\mathrm{l} / \mathrm{s} / \mathrm{m}\end{array}$ & \begin{tabular}{|}
12 Uniformly \\
distributed Cis: \\
$\mathrm{U}(-10-0 ; \ldots$ \\
$\mathrm{U}(100-110)$ \\
Distribution \\
based on \\
inputs (see \\
Equation 10).
\end{tabular} & \begin{tabular}{|} 
Railway \\
nodes, \\
$\begin{array}{c}\text { Near-coastal } \\
\text { nodes }\end{array}$
\end{tabular} & $\begin{array}{c}\text { If } E S W L \geq H, q=-10 \\
\text { Else If } E S W L<(W * \theta), \mathrm{q}=0 \\
\text { Else } \\
q=0.00028 *\left(\mathrm{~h} . *\left(\frac{\mathrm{H}}{\mathrm{Hs}}\right)\right)^{-3.1} * \mathrm{~h}^{2} * \sqrt{g h^{2}} \\
(13)\end{array}$ & \begin{tabular}{|} 
Water Level at toe $(h)$, \\
Hs, Tp, Crest Height \\
$(H)$, impulsive/non- \\
impulsive ( $h *$ ), Beach \\
width, run-up (if \\
applicable)
\end{tabular} & $\begin{array}{l}\text { Overtopping calculated assuming } \\
\text { vertical seawall } \\
\text { Water level at toe, } h \text {, is equal to } \\
\text { flood source water level; } \\
q=-10 \text { state indicates failure } \\
\text { Wave conditions are impulsive ( } h * \\
<0.2 \text { holds true for all simulated } \\
\text { cases) }\end{array}$ \\
\hline $\begin{array}{l}\text { All other nodes } \\
\text { (Estuarine Beaches } \\
\text { from Beach_west1 } \\
\text { to Beach Mouth; } \\
\text { Harbour; Railway } \\
\text { nodes; Near- } \\
\text { coastal; urban FP }\end{array}$ & $\begin{array}{l}\text { Modelled: } \\
\text { Probability } \\
\text { of Flooding } \\
0 \text { to } 1 \text { (no } \\
\text { dimension) }\end{array}$ & $\begin{array}{l}\text { Discrete, } 2 \\
\text { values }(0,1) \\
\text { Distribution } \\
\text { based on } \\
\text { inputs (see } \\
\text { Equation } 10 \text { ) }\end{array}$ & $\begin{array}{c}\text { Near-coastal } \\
\text { nodes, } \\
\text { urban FP }\end{array}$ & $\begin{array}{c}\mathrm{P}(N=\text { flooded })= \\
\sum_{i=1}^{p} P\left(N u_{i}=\text { flooded } \& h(N) \leq h\left(N u_{i}\right)\right)\end{array}$ & $\begin{array}{l}\text { Node } \mathrm{N} \text {, node height, } \\
\mathrm{h} \text {; Heights and flood } \\
\text { states of upstream } \\
\text { nodes, } N u_{i} \text { for } \mathrm{i}=1 \text { to } \mathrm{p}\end{array}$ & $\begin{array}{c}\text { Extreme case of all upstream } \\
\text { elements flooded also considered by } \\
\text { comparing element height with max } \\
\text { ESWL } \\
\text { Average node height obtained from } \\
10 \mathrm{~m} \text { resolution DEM }\end{array}$ \\
\hline
\end{tabular}


$\mathrm{Bn}$ model results were compared with publicly available flood maps to evaluate the effect of network structure, and node definitions and resolutions. A direct comparison with the UK Environment Agency (EA) Indicative Flood Map (IFM) based on a current 1 in 1000 year flood event is shown in Figure 8. The EA IFM is obtained with a bath-tub model based on a raster Digital Elevation Model (DEM) (Environment Agency, 2012a). In the Bn model a node is considered flooded if it has a non-zero probability of flooding. Both maps are obtained under the assumption that there are no flood defences in place. There is good (93\%) agreement in flooded area between the two maps and good spatial agreement in flood extents. The differences illustrate the influence of hydraulic connectivity, node definition and node resolution on $\mathrm{Bn}$ model results. The EA IFM shows flooding to the north of the railway line, which does not occur in the $\mathrm{Bn}$ model due to the railway line preventing hydraulic connectivity. The Bn model shows more coastal flooding since it explicitly includes beach nodes that are shown as flooded. The Bn model defines the urban floodplain node at the town centre more coarsely than the EA IFM resulting in a larger flood extent.

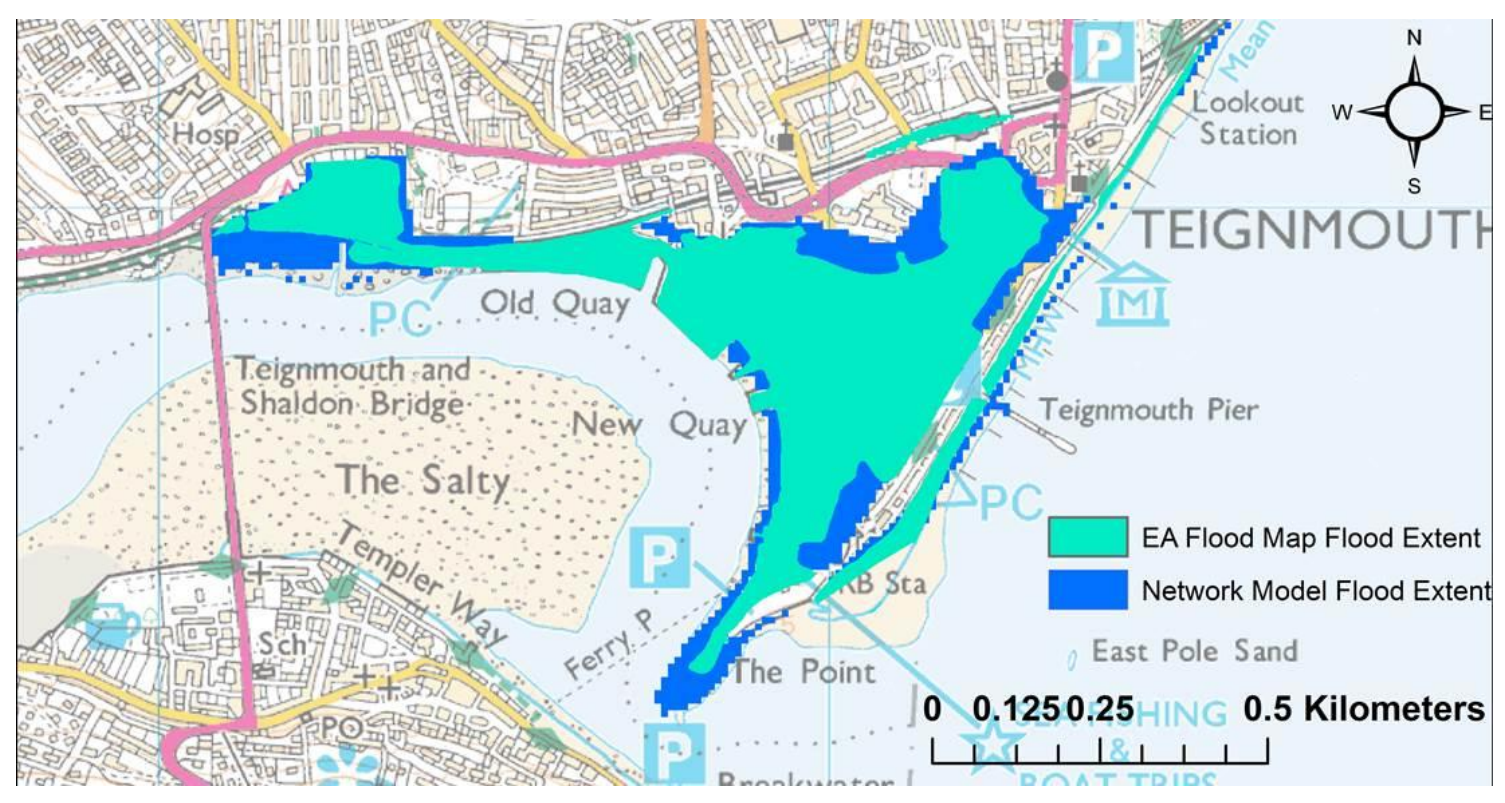

Figure 8: Comparison of Teignmouth network model and EA Indicative flood maps for a 1 in 1000 year ESWL (3.46 m) assuming no defences

Nodes with more than two states will also be affected by the choice of discretisation interval (Pearl, 2011). In this model, all nodes except the seawalls have only two flood states. To evaluate the effect of node discretisation on the seawalls, overtopping rates for one seawall - 'Seawall 1991' (see Figure 6), are compared with rates for a comparable seawall section and similar hydraulic parameters from an engineering study (Mouchel Parkman, 2008; seawall section 208m39c). The comparison is done for three water levels corresponding to 1 in 100 year water levels in the 2020s, 2050s and 2080s (Table 2; water levels from Mouchel Parkman, 2008). The seawalls are assumed to be vertical and wave loading is assumed to be impulsive. Wave height and wave period are $4.1 \mathrm{~m}$ and $8.5 \mathrm{~s}$ respectively, based on the values reported in Mouchel Parkman (2008). 
Table 2: Input values for overtopping calculations

\begin{tabular}{|l|l|l|l|}
\hline Time-slice & Water level $(\mathrm{m})$ & Hs $(\mathrm{m})$ & Tp (s) \\
\hline $2020 \mathrm{~s}$ & 3.36 & 4.1 & 8.5 \\
\hline $2050 \mathrm{~s}$ & 3.51 & 4.1 & 8.5 \\
\hline $2080 \mathrm{~s}$ & 3.66 & 4.1 & 8.5 \\
\hline
\end{tabular}

Results from the two calculations are compared in Figure 8. Given that the input parameters and overtopping formulae are the same, no differences are expected. Rather, this comparison demonstrates the ability of the Bn model to account for overtopping. The exercise also illustrates the importance of node discretisation which is discussed later in this paper. Since overtopping rates are sensitive to the input water levels, care was taken to discretise the flood source node states based on the water levels of interest.

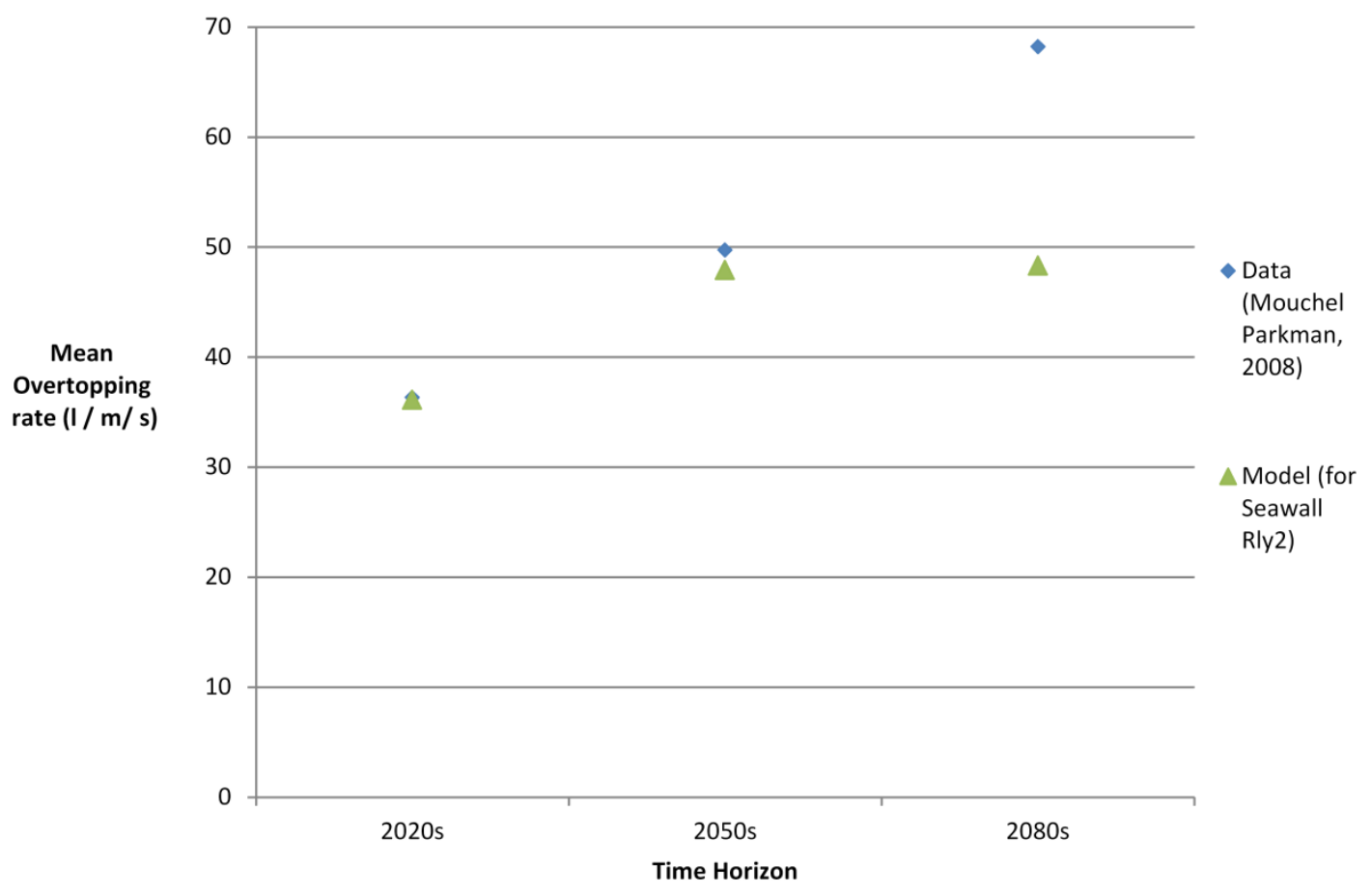


Figure 9: Comparison of Mouchel Parkman (2008) and BN model results for mean overtopping rates at node 'Seawall 1991'.

\section{Flood Pathway Analyses}

The $\mathrm{Bn}$ model is now used to assess the influence of flood pathway changes on flood extents. First, flood extents across the entire floodplain are assessed for current source and pathway conditions, with the new estuarine defences and the open coast seawalls included. Flooding is analysed for multiple ESWLS corresponding to 1 in 10, 1 in 50, 1 in 200 and 1 in 1000 year return period events (Table 3; McMillan et al. 2011). The wave height and period are maintained constant for all simulations at 50 year return period values of $2 \mathrm{~m}$ and $8 \mathrm{~s}$, respectively. Node states are translated to a flood extent map using GIS software (Figure 10).

Table 3: Extreme still water levels and return periods for Teignmouth (from McMillan et al. 2011 )

\begin{tabular}{|c|c|c|}
\hline $\begin{array}{c}\text { Simulation } \\
\text { No. }\end{array}$ & Return Period (years) & Extreme Still Water Level (m) \\
\hline 1 & 10 & 2.97 \\
\hline 2 & 50 & 3.13 \\
\hline 3 & 200 & 3.28 \\
\hline 4 & 1000 & 3.46 \\
\hline
\end{tabular}




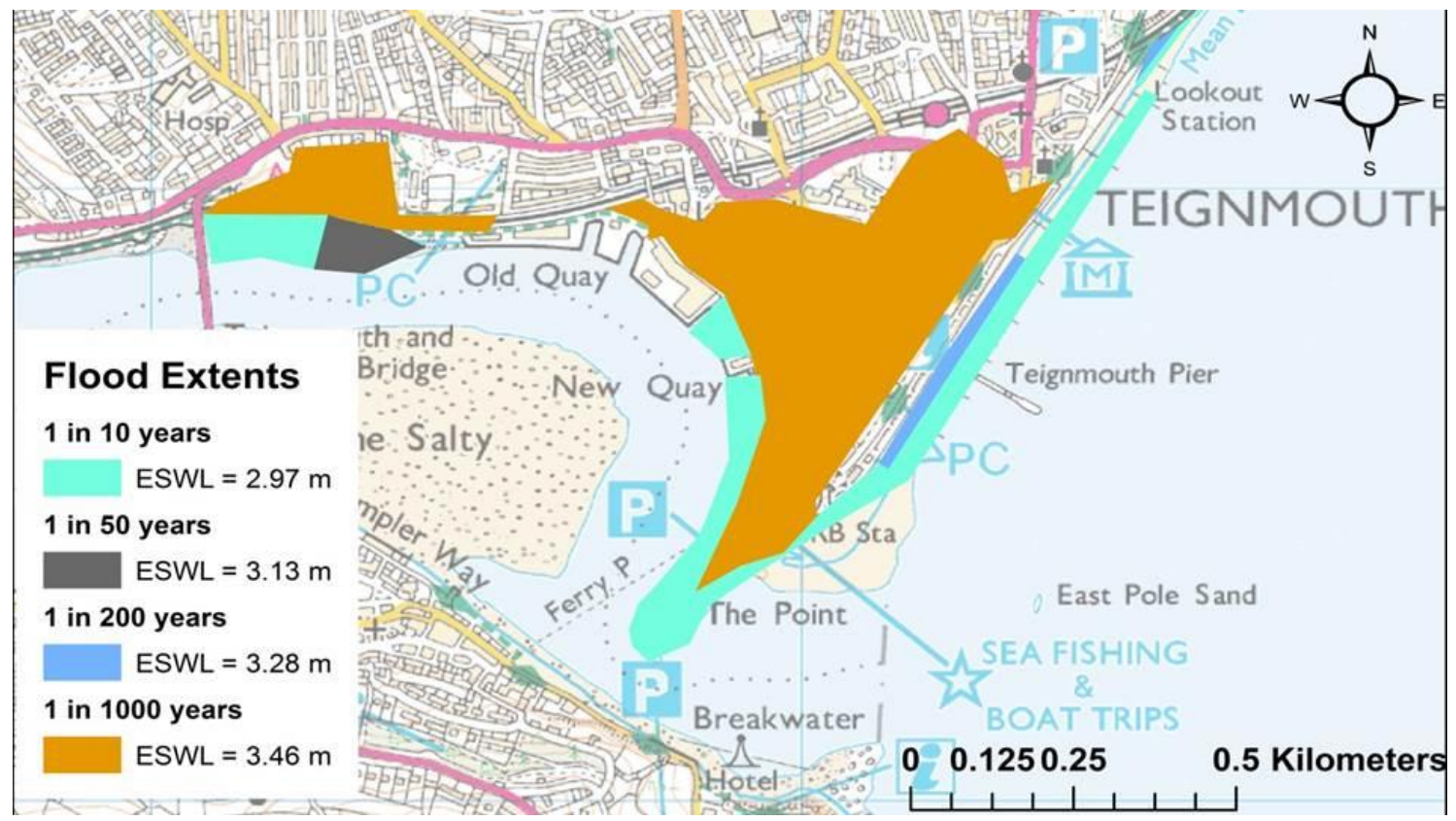

Figure 10: Network model flood extents for four extreme still water levels with the new 1 in 200 year estuarine tidal-flood defence

The results (Figure 10) illustrate the importance of the estuarine flood defences for low-magnitude inundation events and also the vulnerability of the open coast defences to higher magnitude events. The new estuarine defences prevent flooding up to a 1 in 200 year water level, though they are inundated at a 1 in 1000 year water level. The seawalls along the open coast are relatively more vulnerable and start flooding at the 1 in 200 water level.

Based on these results, a sensitivity analysis of the open coast pathways is done. Though they do not flood under current conditions, combinations of higher water levels and lower beach widths can alter these pathways to cause flooding inland. Indeed the persistence of storm tracks due to a clustering of storms such as the 2014 winter UK storms (Slingo et al., 2014) could contribute to significant beach lowering and increased vulnerability of the sea walls (Roelvink et al., 2009).

The pathway analyses are based on a) published allowance for sea-level rise under the most reasonable IPCC scenario and isostatic rebound; and b) sediment input scenarios based on shoreline management plans in the region (UK Government, 2006). Six cases comprising three sea level rise and two sediment input scenarios are simulated (Table 4). All six cases are run over a baseline 1 in 200 year water level with added sea-level rise for years AD 2010, 2050 and 2100 (UK Climate Projections, 2009). The wave height and period are maintained constant for all cases at 50 year return period values of $2 \mathrm{~m}$ and $8 \mathrm{~s}$. Fronting beach widths are assumed to be $15 \mathrm{~m}$ with nourishment and $5 \mathrm{~m}$ without nourishment. When external sediment input is unknown, beach width is uniformly distributed across the entire $0-20 \mathrm{~m}$ interval. Figure 11 shows the flood pathways analysed from these simulations. To isolate the influence of the open pathways in these simulations, it is assumed that the estuarine defences will not flood. This 
is based on the expectation that these defences will be raised to accommodate future sea-level rise (Environment Agency, 2012b).

Table 4: Sea-level rise (SLR), extreme still water level (EWSL) and Sediment Input cases for Teignmouth network model simulations. (B): Baseline event

\begin{tabular}{|c|c|c|c|c|}
\hline $\begin{array}{c}\text { Case } \\
\text { No. }\end{array}$ & $\begin{array}{c}\text { Time-Horizon } \\
\text { (year) }\end{array}$ & SLR $(\mathbf{m})$ & ESWL $(\mathbf{m})$ & Sediment Input \\
\hline $1(B)$ & 2010 & 0 & 3.28 & Present \\
\hline 2 & 2010 & 0 & 3.28 & Unknown \\
\hline 3 & 2050 & 0.15 & 3.43 & Present \\
\hline 4 & 2050 & 0.15 & 3.43 & Unknown \\
\hline 5 & 2100 & 0.5 & 3.78 & Unknown \\
\hline 6 & 2100 & 0.5 & 3.78 & \\
\hline
\end{tabular}




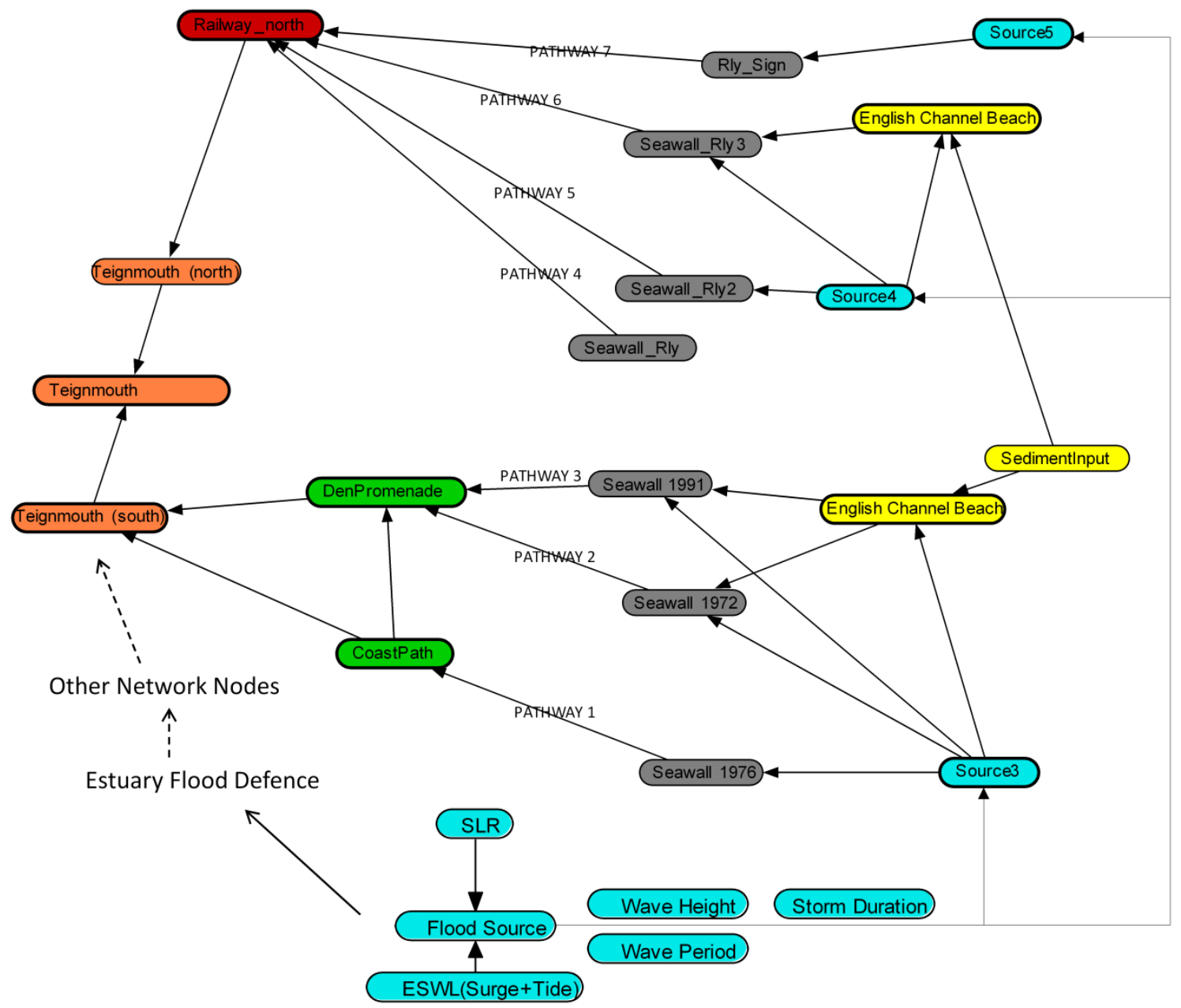

Figure 11: Truncated network showing only open coast flood pathways to inland node 'Teignmouth'

The node probabilities for pathways 1 to 7 are plotted in Figure 12 below for the most severe case (Case 6 , Table 4) of a $0.5 \mathrm{~m}$ rise in sea-level and unknown sediment input. 


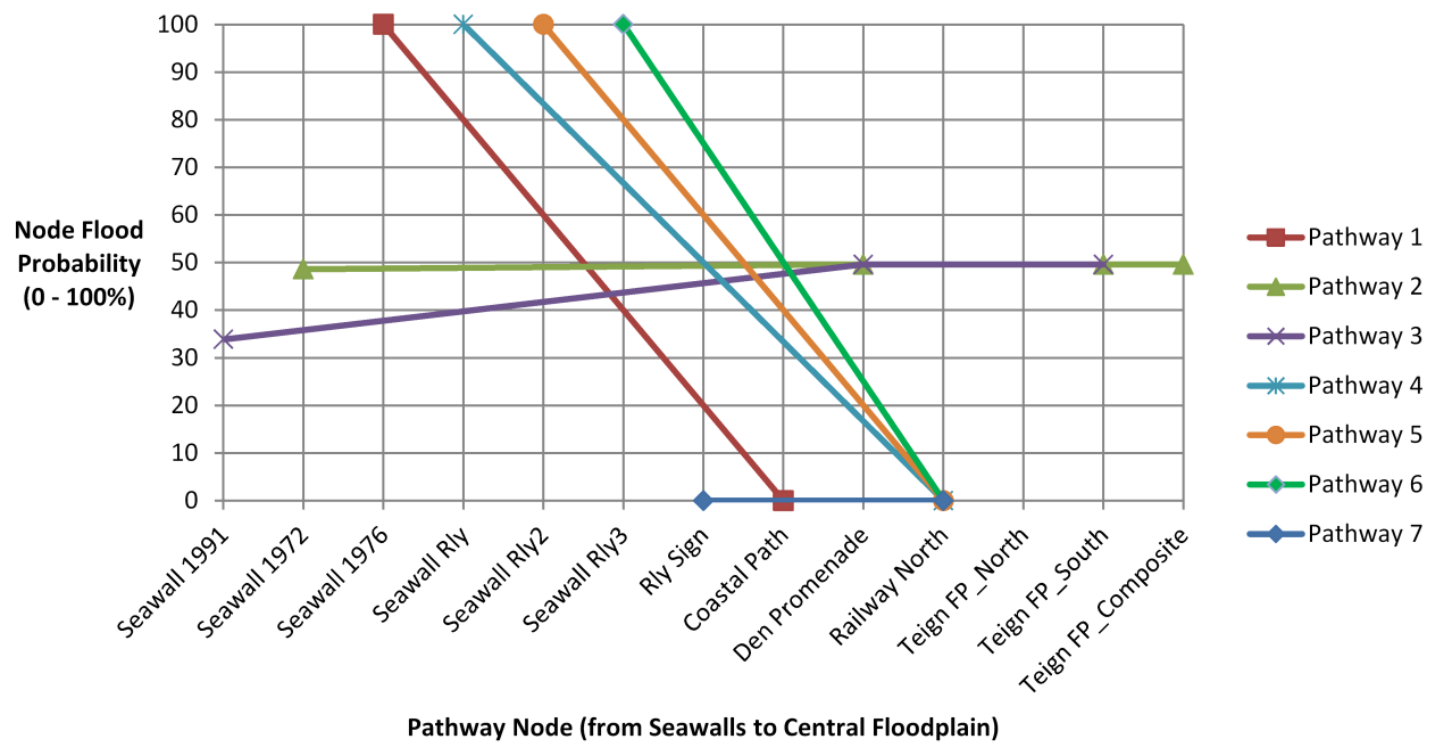

Figure 12: Flood probabilities of network nodes along all open coast pathways

\section{numbered in Figure 11}

All except two pathways - Pathways 2 and 3 - remain dry even though most of the seawalls are flooded. This is due to the walls, walkway and railway line behind these seawalls that effectively act as secondary flood barriers. Though the seawalls in pathways 2 and 3 show less chance of being overtopped, they form critical flood pathways to the inland floodplain due to an absence of similar secondary flood barriers. Between the two, Seawall 1972 on pathway 2 shows higher flood probabilities.

Both seawalls are strongly influenced by the width of their fronting beaches. When sediment input is available these beaches are wide and form effective flood defences for all sea-level rise scenarios. When this input is uncertain the probability of a low beach width increases and consequently the probability of flooding at the seawalls also increases. The influence of beach widths becomes especially critical with rising sea-levels. To illustrate the influence of sea-level rise on these pathways, the flood probabilities for all the nodes along pathways 2 and 3 are plotted against sea-level in Figure 13 assuming 'unknown' Sediment Input. A considerable increase is observed in chances of seawall flooding due to sea-level rise and a consequent increase in flood probabilities at the inland nodes of both pathways. 


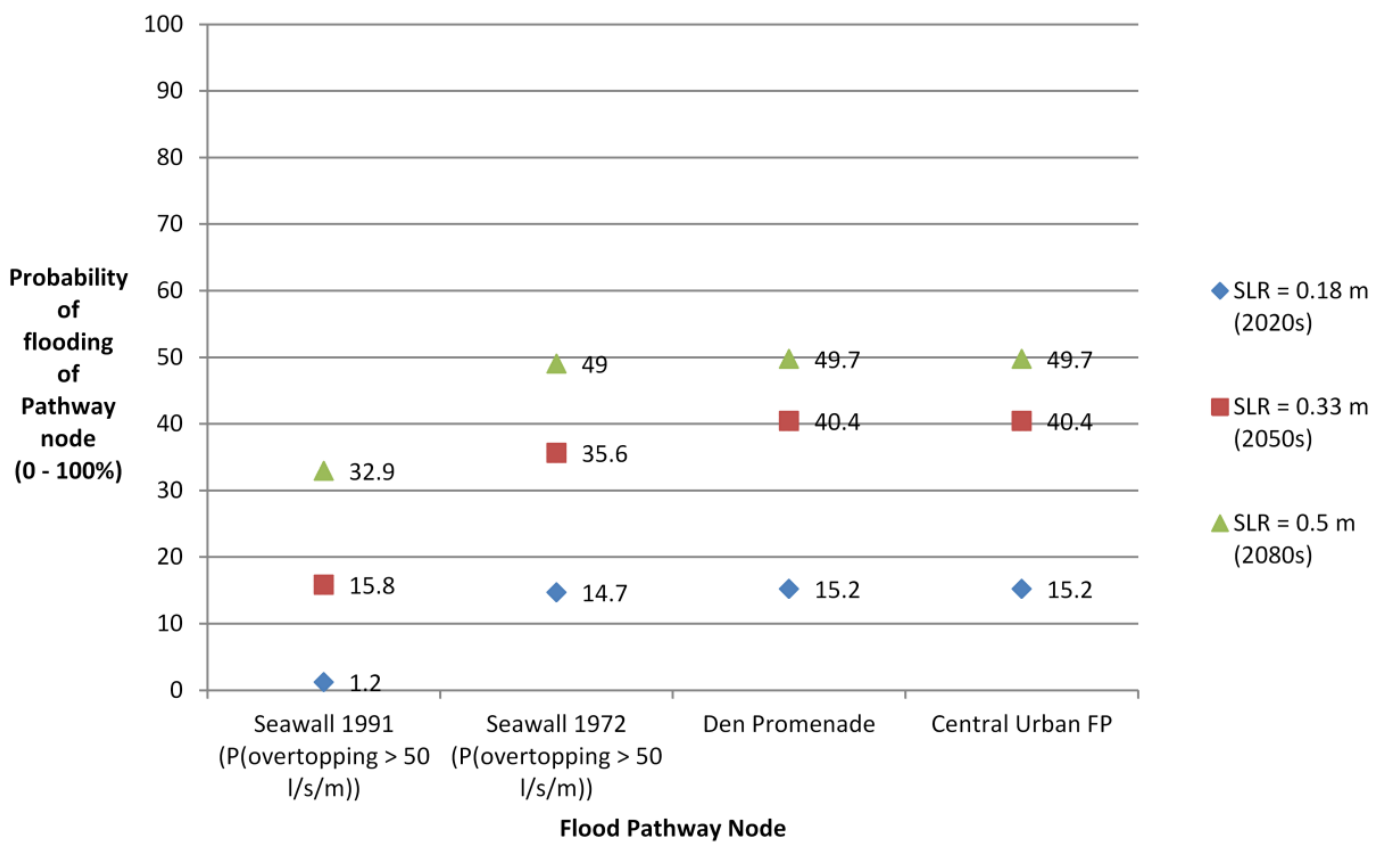

Figure 13: Node flood probabilities versus sea-level rise, for pathways 2 and 3, for ‘unknown' Sediment Input

\section{Discussion}

Based upon the inputs provided, the Bn model shows that the critical floodplain elements for the Teignmouth network are limited to a few coastal elements that influence overtopping rates and hydraulic connectivity. While this may be straightforward to deduce from the information gathered during $\mathrm{Bn}$ model construction, the model itself provides a structured way in which to combine and quantitatively assess information across all the floodplain nodes.

In this case-study the Quasi-2D SPR was constructed following consultation with local coastal engineering and flood risk experts. The Quasi-2D SPR was developed as a participatory model, to encapsulate a shared, comprehensive description of the expert, technical and historical knowledge of this coastal floodplain. The floodplain description for Teignmouth can be improved by extended the participatory approach to include ecologists, land-use planners and other local stakeholders as has been done for other coastal regions (Narayan et al., 2014) and through further discussion and calibration of its outputs with local experts and other stakeholders.

In comparison to a bath-tub model the Bn model can provide improved representation of flooding through incorporation of elevation, hydraulic connectivity and node-specific flood propagation relationships, whilst remaining relatively quick to develop and run. The Bn model is capable of handling a variety of node descriptions and flood propagation relationships. Specific pathway elements that can significantly influence flood propagation such as secondary barriers behind the seawalls are also easily included and their effects quantified with this model. Knowledge gaps and uncertainties, such as the 
limited information on sediment input and beach width, are shown to have a large influence on overtopping rates and flood extents.

Bn model nodes are derived from the Quasi-2D SPR system diagram which uses a vector mapping process. Choices about the network structure, node descriptions and node resolutions therefore depend on the scale and objective of the study. Narayan et al. (2012b) provide a discussion of the influence of scale on Quasi-2D SPR models. In the Teignmouth case-study, the scale selected is appropriate to the size of the local floodplain with the aim of providing an overview of the structure of likely flooding events. While it does not quantify the uncertainties introduced by the spatial averaging of elevation, the Teignmouth case-study provides support for the validity of the Bn model through testing its network structure, node descriptions and node discretisation intervals. The network structure is tested by comparing flood extent results with the EA IFM. While the $\mathrm{Bn}$ model resolves some network elements less precisely, such as the central urban floodplain, in comparison to the EA IFM, it does a better job in representing the absence or presence of hydraulic connectivity between nodes. Improvement to the resolution of the $\mathrm{Bn}$ model would require more detailed node definitions, making the network more complex and its construction more cumbersome. Although the vector-based approach appears cruder, a great advantage is that it does allow the inclusion of intricate, but essential features that could not be resolved in raster models without significantly increasing their resolution. These include elements such as linear seawalls, flood barriers, railway lines, etc., all of which critically affect hydraulic connectivity. Also, the $\mathrm{Bn}$ model is more flexible in the manner in which it can represent different types of floodplain node such as the in the use of beach width to capture beach behaviour, and overtopping to represent sea wall performance.

This $\mathrm{Bn}$ model has been used here in an unconventional manner. Bn models are typically employed to derive the forward estimation of probability from statistical data (e.g. Peng and Zhang, 2012). Here the approach uses well established and empirical relationships to estimate flood propagation probabilities. Where nodes with more than two states are required, such as the representation of water levels corresponding to specific events, the discretisation of node-state intervals becomes critical. For instance, lumping two water levels within the same node-state interval will not allow the Bn model to distinguish between them when sampling. The upper and lower bound values of these nodes should also be chosen carefully. Bn models assume that there is a zero probability of a node taking a value outside its defined range. This limitation is addressed by using conservative upper bound values that are not expected to be exceeded. For this reason, the Quasi - 2D SPR and Bn model are constructed for the maximum expected coastal flood event. A related limitation of the model is that it does not account for feedback relationships in case of an event outside the expected range. For instance, it is possible, though unlikely, that an extreme estuarine water level could flood the entire network up to some of the open coast seawalls, and vice versa. The Bn model's network is a 'directed acyclic graph' - which means that feedback loops are not permitted. This issue could be addressed through the use of a dynamic $\mathrm{Bn}$ model. A simpler option is to consider all the inland nodes to be flooded if the input water levels exceed a specified threshold.

In this work we have only considered coastal flood sources. As with other estuarine locations, flooding in Teignmouth could be exacerbated by fluvial and/or pluvial events. This could increase water levels in the 
estuary and increase the floodplain extent, adding new flood pathways. This Bn model uses five flood source nodes at different locations along the estuary and open coast. However, the flood water level associated with each of the five sources is the same sum of surge, tide and sea-level rise components. Additional information on fluvial events from the Teign estuary can be readily incorporated by the addition of a fluvial water level component to the estuarine sources. In the case-study, the water level nodes are discrete values corresponding to discrete events. Information on probability distributions of water levels can be included at these nodes for a more comprehensive description of flood probabilities. The case study also does not assess flood depths or flood impacts to pathway elements. The ability to include information on the state of a floodplain node or the health of a flood defence node will be a useful extension to the model's capabilities in assessing flood pathways.

\section{Conclusions}

A Quasi-2D Bayesian network model is developed for simulation of inundation pathways and probabilities in a coastal floodplain. The $\mathrm{Bn}$ model is derived from a Quasi-2D SPR system diagram and facilitates inclusion of knowledge gained from a participative mapping process into coastal inundation analysis.

Together, the Quasi-2D SPR and Bn models offer a tool that a) provides a whole-systems overview of the floodplain; b) encourages critical thinking about the floodplain system and the role of individual elements in flood propagation; and c) identifies critical flood pathways and uncertainties. Collectively, the models help to gather and structure information about the floodplain in a manner that can inform and target further analysis, including more detailed numerical modelling, data collection campaigns and risk assessments.

The approach here is different from conventional use of Bn models, in that it uses network connectivity and basic flood propagation rules to provide an overview of likely flood event extents and assessment of the relative importance of flood pathways expressed as probabilities. It is constructed over only a few days for the town of Teignmouth in the UK, with a population of around 15,000 and a floodplain extent of 1 to $2 \mathrm{~km}^{2}$. Each simulation takes approximately one minute on a standard PC and involves a total of 200,000 conditional probabilities across 50 network nodes. The case-study demonstrates the applicability of the Bn model to coastal floodplains consisting of several network nodes and links and identifies the critical importance of a few particular coastal elements.

The case study and model do not estimate flood depths or flood impacts. The Bn model cannot be - and is not intended to be - a substitute for conventional 2D and 3D inundation models that assess these parameters. Rather, it provides rapid assessments of flood pathways to inform detailed numerical analyses. By including further node attributes the approach could also be extended to allow assessment of flood impacts and their effects on future pathway states. Further work will focus on: comprehensive representation of pathway element states, especially coastal defences; probabilistic representation of water levels and wave heights; and applications of this approach to urban coastal floodplains with a greater degree of hydraulic complexity. The approach could also readily be extended to situations that include fluvial and pluvial flood sources, the influence of sewer and drainage systems and infrastructure- 
related floodplain elements. However, the utility of this approach remains its ability, in comparison to other approaches, to create rapid descriptions of floodplain networks which encapsulate expert knowledge. These representations incorporate the adopted EA SPR conceptual model philosophy. The method facilitates a reduction in system complexity that allows flood managers to get to the heart of their flooding problems before committing resources for detailed further analysis.

\section{Acknowledgements}

The support of the European Commission through the project "Innovative Technologies for safer European coasts in a changing climate" (THESEUS), Contract 244104, FP7.2009-1, www.theseusproject.eu, is gratefully acknowledged. The authors are very grateful to Dr. Raul Gonzalez, Research Fellow at the School of Marine Science and Engineering, Plymouth University for providing data for the network model. The authors are also grateful to Prof. Richard Thompson and Dr. Simon Hoggart of this school and Prof. Dominic Reeve, College of Engineering, Swansea University, for their assistance with the Teignmouth Quasi-2D SPR system diagram. The feedback and comments from Prof. Jim Hall, Director, Environmental Change Institute, University of Oxford and Dr. Costantino Manes, Faculty of Engineering and the Environment, University of Southampton, on the work described in this paper are gratefully acknowledged. The comments of the two anonymous reviewers were invaluable in strengthening this paper and their contributions are gratefully acknowledged.

\section{References}

DAWSON, R., DICKSON, M., NICHOLLS, R., HALL, J., WALKDEN, M., STANSBY, P., MOKRECH, M., RICHARDS, J., ZHOU, J., MILLIGAN, J., JORDAN, A., PEARSON, S., REES, J., BATES, P., KOUKOULAS, S. \& WATKINSON, A. 2009. Integrated analysis of risks of coastal flooding and cliff erosion under scenarios of long term change. Climatic Change, 95, 249-288.

DEN HEIJER, C. K., KNIPPING, D. T., PLANT, N. G., DE VRIES, J. S. V. T., BAART, F. \& VAN GELDER, P. H. 2012. Impact assessment of extreme storm events using a Bayesian network. Coastal Engineering Proceedings, v33, DOI: http://dx.doi.org/10.9753/icce.v33.management.4.

ENVIRONMENT AGENCY. 2012a. Flood Maps [Online]. UK: EA. Available: http://www.environmentagency.gov.uk/homeandleisure/37837.aspx [Accessed February 20 2012].

ENVIRONMENT AGENCY. 2012b. Safeguarding Teignmouth [Online]. http://www.environmentagency.gov.uk/homeandleisure/floods/103500.aspx. [Accessed August 10th 2013].

ENVIRONMENT AGENCY 2012. South Devon Catchment Flood Management Plan: Summary Report 2012. Exeter: Environment Agency.

EUROTOP MANUAL 2007. Wave Overtopping of Sea Defences and Related Structures: Assessment Manual. UK: NWH Allsop, T. Pullen, T. Bruce. NL: JW van der Meer. DE: H. Schüttrumpf, A. Kortenhaus. wWw. overtopping-manual. com.

FLOODSITE CONSORTIUM 2009. Methodology for a DSS to support long-term Flood Risk Management Planning. Report No. T-18-09-02. In: MCGAHEY, C. (ed.) Integrated Flood Risk Analysis and Management Methodologies. H R Wallingford. Available at: http://www.floodsite.net/html/publications3.asp?taskID=18. [Accessed July 12 2014].

FRENCH, J. \& BURNINGHAM, H. Qualitative mathematical modelling of coupled coast and estuary morphodynamics: a modified Boolean network approach. AGU Fall Meeting Abstracts, 2011. 0888. 
GUARDIAN WITNESS. 2014. Waves hitting the promenade at Teignmouth [Online]. Teignmouth. Available: https://witness.theguardian.com/assignment/52a028a8e4b0acc591790cd5/753106 [Accessed July 20 2014].

GUTIERREZ, B. T., PLANT, N. G. \& THIELER, E. R. 2011. A Bayesian network to predict coastal vulnerability to sea level rise. Journal of Geophysical Research: Earth Surface, 116, F02009.

HALCROW GROUP 2011. Shoreline Management Plan Review (SMP2): Durlston Head to Rame Head. In: SOUTH DEVON AND DORSET COASTAL ADVISORY GROUP (ed.). Halcrow, Exeter, U.K.

HALL, J. W., MEADOWCROFT, I. C., SAYERS, P. B. \& BRAMLEY, M. E. 2003. Integrated flood risk management in England and Wales. Natural Hazards Review, 4, 126.

HALLEGATTE, S., GREEN, C., NICHOLLS, R. J. \& CORFEE-MORLOT, J. 2013. Future flood losses in major coastal cities. Nature Climate Change, 3, 802 - 806.

KARUNARATHNA, H. \& REEVE, D. 2008. A Boolean Approach to Prediction of Long-Term Evolution of Estuary Morphology. Journal of Coastal Research, 51-61.

KELLY, R. A., JAKEMAN, A. J., BARRETEAU, O., BORSUK, M. E., ELSAWAH, S., HAMILTON, S. H., HENRIKSEN, H. J., KUIKKA, S., MAIER, H. R., RIZZOLI, A. E., VAN DELDEN, H. \& VOINOV, A. A. 2013. Selecting among five common modelling approaches for integrated environmental assessment and management. Environmental Modelling \& Software, 47, 159-181.

KORTENHAUS, A., OUMERACI, H., WEISSMAN, R. \& RICHWIEN, W. Failure mode and fault tree analysis for sea and estuary dikes. COASTAL ENGINEERING CONFERENCE, 2002. ASCE AMERICAN SOCIETY OF CIVIL ENGINEERS, 2386-2398.

KRON, W. 2013. Coasts: the high-risk areas of the world. Natural Hazards, 66, 1363-1382.

MCGRANAHAN, G., BALK, D. \& ANDERSON, B. 2007. The rising tide: assessing the risks of climate change and human settlements in low elevation coastal zones. Environment and Urbanization, 19, 1737.

MCMILLAN, A., BATSTONE, C., WORTH, D., TAWN, J., HORSBURGH, K. \& LAWLESS, M. 2011. Coastal flood boundary conditions for UK mainland and islands. Project SC060064/TR2: Design sea levels.

MOKRECH, M., HANSON, S., NICHOLLS, R., WOLF, J., WALKDEN, M., FONTAINE, C., NICHOLSON-COLE, S., JUDE, S., LEAKE, J., STANSBY, P., WATKINSON, A., ROUNSEVELL, M. A., LOWE, J. \& HALL, J. 2011. The Tyndall coastal simulator. Journal of Coastal Conservation, 15, 325-335.

MONBALIU, J., CHEN, Z., FELTS, D., HISSEL, F., KAPPENBERG, J., NARAYAN, S., NICHOLLS, R. J. \& WILLEMS, P. 2014. Risk assessment of estuaries under climate change: lessons from Western Europe. Coastal Engineering.

MOUCHEL PARKMAN 2008. Impact of Climate Change on Transport Infrastructure. Research Programme: Engineering. Surrey, UK: Rail Safety and Standards Board.

NARAYAN, S. 2014. A Conceptual Model and Rapid Appraisal Tool for Integrated Coastal Floodplain Assessments. PhD, University of Southampton.

NARAYAN, S., HANSON, S., NICHOLLS, R. J., CLARKE, D., WILLEMS, P., NTEGEKA, V. \& MONBALIU, J. 2012a. A Holistic Model for Coastal Flooding using Systems Diagrams and the Source - Pathway Receptor (SPR) Concept. Nat. Hazards Earth Syst. Sci, 12, 1431-1439.

NARAYAN, S., KEBEDE, A. S., NICHOLLS, R. J., CLARKE, D., LE COZANNET, G. \& HISSEL, F. An investigation of scale issues using a conceptual systems model. In: KLIJN, F. \& SCHWECKENDIEK, T., eds. FLOODrisk 2012, 2012b Rotterdam, Netherlands. CRC Press, 38.

NARAYAN, S., NICHOLLS, R. J., CLARKE, D., HANSON, S., REEVE, D., HORRILLO-CARABALLO, J., LE COZANNET, G., HISSEL, F., KOWALSKA, B., PARDA, R., WILLEMS, P., OHLE, N., ZANUTTIGH, B., LOSADA, I., GE, J., TRIFONOVA, E., PENNING-ROWSELL, E. \& VANDERLINDEN, J. P. 2014. The SPR systems model as a conceptual foundation for rapid integrated risk appraisals: Lessons from Europe. Coastal Engineering, 87, 15-31. 
NICHOLLS, R. J., BRADBURY, A., BURNINGHAM, H., DIX, J., ELLIS, M., FRENCH, J., HALL, J. W., KARUNARATHNA, H. U., LAWN, J. \& PAN, S. 2012. iCOASST-integrating coastal sediment systems. International Conference on Coastal Engineering, Proceedings, 1, sediment. 100.

NORSYS SOFTWARE CORP 2010. Netica C - API Manual. In: NORSYS SOFTWARE CORP (ed.). Vancouver. PEARL, J. 2000. Causality: models, reasoning and inference, Cambridge Univ Press.

PEARL, J. 2011. Bayesian networks. eScholarship University of California [Online]. Available: http://www.escholarship.org/uc/item/53n4f34m.

PENG, M. \& ZHANG, L. 2012. Analysis of human risks due to dam-break floods-part 1: a new model based on Bayesian networks. Natural Hazards, 64, 903-933.

PLYMOUTH COASTAL OBSERVATORY. 2014. Southwest Regional Coastal Monitoring Programme [Online]. Plymouth: Channel Coastal Observatory. Available: http://www.channelcoast.org/southwest/ [Accessed July 20 2014].

PURVIS, M. J., BATES, P. D. \& HAYES, C. M. 2008. A probabilistic methodology to estimate future coastal flood risk due to sea level rise. Coastal Engineering, 55, 1062-1073.

ROELVINK, D., RENIERS, A., VAN DONGEREN, A., VAN THIEL DE VRIES, J., MCCALL, R. \& LESCINSKI, J. 2009. Modelling storm impacts on beaches, dunes and barrier islands. Coastal Engineering, 56, 1133-1152.

ROYAL HASKONING 2011. Level 2 Strategic Flood Risk Assessment: Technical Element. In: COUNCIL, T. D. (ed.). Teignbridge District Council, Exeter, Devon.

SAYERS, P., HALL, J., DAWSON, R., ROSU, C. Chatterton J., \& Deakin, R. 2002. Risk assessment of flood and coastal defences for strategic planning (RASP)-a High Level Methodology. DEFRA Conference of Coastal and River Engineers, Keele University, HR Wallingford.

SCHULTZ, M. 2012. Modelling the Effect of Sea-Level Rise on Risks to Coastal Infrastructure using Bayesian Networks. Transportation Research Board Conference. Washington D.C.: Engineer Research and Development Center, USACE.

SLINGO, J., BELCHER, S., SCAIFE, A., MCCARTHY, M., SAULTER, A., MCBEATH, K., JENKINS, A., HUNTINGFORD, C., MARSH, T., HANNAFORD, J. \& PARRYL, S. 2014. The Recent Storms and Floods in the UK. Exeter: Met Office.

SPIEGELHALTER, D. J., DAWID, A. P., LAURITZEN, S. L. \& COWELL, R. G. 1993. Bayesian Analysis in Expert Systems. Statistical Science, 8, 219-247.

STEWART-KOSTER, B., BUNN, S., MACKAY, S. J., POFF, N., NAIMAN, R. \& LAKE, P. 2010. The use of Bayesian networks to guide investments in flow and catchment restoration for impaired river ecosystems. Freshwater Biology, 55, 243-260.

THE SOUTH WEST COAST PATH. 2014. Teignmouth: Seawall to Holcombe temporarily closed [Online]. Teignmouth. Available: http://www.southwestcoastpath.com/diversiondb/52/.

UK CLIMATE PROJECTIONS. 2009. Sea-level change estimates [Online]. Available at: http://www.ukcip.org.uk/resources/ukcp09-sea-level-change/. 2013].

UK GOVERNMENT 2006. Planning Policy Statement 25: Development and Flood Risk. London: The Stationery Office.

VILLATORO, M., SILVA, R., MÉNDEZ, F. J., ZANUTTIGH, B., PAN, S., TRIFONOVA, E., LOSADA, I. J., IZAGUIRRE, C., SIMMONDS, D., REEVE, D. E., MENDOZA, E., MARTINELLI, L., FORMENTIN, S. M., GALIATSATOU, P. \& EFTIMOVA, P. 2014. An approach to assess flooding and erosion risk for open beaches in a changing climate. Coastal Engineering, 87, 50-76.

VIZARD, N. 2012. Teignmouth flood alleviation scheme to officially open Friday [Online]. Teignmouth: The Exeter Daily. Available: http://www.theexeterdaily.co.uk/news/local-news/teignmouthflood-alleviation-scheme-officially-open-friday [Accessed July 10 2014].

YATES, M. L. \& LE COZANNET, G. 2012. "Evaluating European Coastal Evolution using Bayesian Networks.". Natural Hazards \& Earth System Sciences, 12, 1173-1177. 
ZANUTTIGH, B., SIMCIC, D., BAGLI, S., BOZZEDA, F., PIETRANTONI, L., ZAGONARI, F., HOGGART, S. \& NICHOLLS, R. J. 2014. THESEUS decision support system for coastal risk management. Coastal Engineering, 87, 218-239.

ZOU, Q. P., CHEN, Y., CLUCKIE, I., HEWSTON, R., PAN, S., PENG, Z. \& REEVE, D. 2013. Ensemble prediction of coastal flood risk arising from overtopping by linking meteorological, ocean, coastal and surf zone models. Quarterly Journal of the Royal Meteorological Society, 139, 298-313. 